\title{
The Professional Study of Military History
}

\section{Colonel Lonsdale Hale}

To cite this article: Colonel Lonsdale Hale (1897) The Professional Study of Military History, Royal United Services Institution. Journal, 41:232, 690-721, DOI: 10.1080/03071849709416036

To link to this article: http://dx.doi.org/10.1080/03071849709416036

\section{曲 Published online: 11 Sep 2009.}

Submit your article to this journal

Џll Article views: 6

Q View related articles $\longleftarrow$ 


\title{
THE PROFESSIONAL STUDY OF MILITARY HISTORY.
}

\author{
By. Colonel LONSDALE HALE (late R.E.).
}

\author{
Wednesday, March 17 th, 1897. \\ Major-General Sir V. F. BuTlER, K.C.B., \\ Commanding South-Eastern District, \\ in the Chair.
}

\section{LECTURE.}

DR. MIAGUIRE brought before us, a few dass ago, the Study of Military History, as a factor in the Training of the Nation; to-day, I bring that study again before you, but this time as a factor in the Training of the Soldier. The two uses of the study must be kept separate, and must not be confused with each other. To emphasise the difference between them, I have introduced into the title of this lecture the word "Pro"fessional."

But, as a military instructor, a military lecturer, I cannot but regard with dislike the title by which the subject of this lecture is generally known; for in it are two words, which, unfortunately, cause not a few officers, but many, to entertain strong prejudices against the subject itself, if not to neglect it or ignore it altogether. The first of these words is "Study," the second is "History," each, in the opinion of these officers, bad enough alone, but when in juxtaposition, forming a combination absolutely detestable. For the corps of British officers consists mainly of men who, if asked the now historic question, "Is life worth living?" would reply with a decided affirmative; but with this answer would be coupled an equally decided reservation, that a very large proportion of the life must be spent in fighting and thrashing somebody or other, this exciting occupation being, at the same time, combined with overcoming those physical obstacles, which-in the form of well-nigh impracticable snow-covered mountain passes, such as lie between India and Chitral, of Burmese and Ashantee jungles, of the waterless deserts of the Soudan, or of the fever-breeding rivers, which are the highways into the heart of Africa-Nature seems purposely to have placed in their way. To the men who regard these unpleasant places as "happy hunting-grounds," men of sinew, thews and muscle, sound in wind and limb, men whose forefathers won, and who themselves are maintaining the territory acquired, and, perhaps, winning yet more, "study" is a 
brain labour both irksome and exhausting; "history" is to them a bad dream, which, in sleep only, after some indigestible repast, comes back to them, recalling in nightmare fashion all the horrors of "crammers," and of the Literary Competitive for Sandhurst or the Militia. I gladly" acknowledge that among these officers are a few who take pleasure in literary study also, and from time to time prove that they can use the pen as effectively as they wield the sword; but these are the exceptions.

With the feclings of the officers who form the majority, I, though a life-long literary student, have the deepest sympathy; I enter into their feelings thoroughly, for I have accepted the teaching of a lesson taught me, years ago, by a very clever woman, the wife of a gencral officer well known to many of my cotemporaries. "What a pleasant thing reading is," I happened to remark to her. "Pleasant?" was the reply, "I hate it." "You hate reading," I said, in utter amazement. "Yes," rejoined my friend; and she continued : "When I want to get hold of some fresh ideas and fresh facts by your pleasant reading, I have to put in front of me a lot of pages of paper, on which are a number of horrid black marks: and there I have to sit or stand, staring at these black marks; and when, after an hour or two of staring, and my eyes aching and tired with the work, I throw the book aside, I, perhaps, find that all I have got out of the mark; is one fresh idea, and half a cloubtful fact. Reading gives one a lot of trouble, and, except from a lot of reading, one gets very little out of it." And anyone who has ever tried to prepare a lecture on one single battle, sare by the simple process known as "scissors and paste," will agree with $\mathrm{my}$ friend, that one does get very little even out of a fair amount of reading. And only the other day, a rising staff officer whom I found in this Institution, studying a campaign, looked up from his books and said to me in weary tones, "What a bore this reading is, this being able to get at the facts only by reading." This, gentlemen, is how reading, involved necessarily in the word "study," is naturally and fairly regarded by a large number of officers of that physical and mental constitution I have indicated to you.

Yet the study of military history, which involves the persistent gazing at a number of these hateful black marks on paper, seems to me to be a necessary part of the training of every officer, senior and junior, old and young; for the mental food thus absorbed strengthens the military mind, and makes any one-no matter the number of the military expeditions in which he may have taken part-a more eflicient, a better soldier than hs would have been without it.

To offer military history, as such, to the non-reading officers, is, however, as thankless a task as is putting before a high-spirited horse a feed of corn in a trough, at either end of which a black flag, bearing a death's head and cross-bones, flutters in the breeze. He is sure to shy at the flags and to bolt away. Yet eat the corn he ought. Cannot it be brought to his notice in some other way, one which, perhaps, so far from repelling him, may even attract him?

I will take that objectionable word " history" first. What is history of any kind? It is the recorded experiences of the past. Then as to 
the word "study." When we study anything, we are utilising it; so for "study" we may fairly, if not with academic precision, substitute the word "utilising." The subject of this lecture stands now, therefore, "The utilising by soldiers the recorded military experiences of the past." And for reasons which will be apparent as I proceed, I ask even the most diligent student of military history who may be present in this theatre, to think of this subject solely in the new form in which I have just presented it to you, "the utilising the recorded military experiences of the past."

And now let me recall to your minds certain features in these experiences, taken collectively. As to amount, they are innumerable; as to time, they are found in every period of the world's history; as to locality, there is hardly one of the countries, if one, into which the surface of the globe is mapped out, from which they cannot be gathered; as to subject, they include every single incident, small or great, with which a soldier, be he full private or full field-marshal, has to deal, or which he encounters in the field; as to the form of record, every conccivable shape, from the letter home to friend, wife, or mother, to the Commentaries of Cxsar. And what a strange collection of contrasts! some, as regards importance or survival in memory, as far apart as the poles. Alexander leading his hosts to India; a cavalry subaltern leading a patrol into Vendome: the point of an advanced guard marching through a hostile village in France; Hannibal crossing the hostile $A l p s$; an encounter of five or six squadrons at Boiscommun in 1870 ; Ziethen or Seidlitz hurling their vast hosts of cavalry against a foe; the punitive expedition to Benin; the hordes of Barbarians marching on to Rome; Cassar, the mighty Cxsar, bridging the Rhine; a German company leader scrambling over the Sal by means of a skeleton framework in a "Fog of War."

And all these innumerable facts lie deposited in strict chronological sequence, in historic strata like those of geological formations; those most approaching the facts of to-day above and near at hand, those most divergent from them deep below. 13ut, strange as it may appear, although each and every one of these recorded experiences is history, the more important facts are sometimes only those which are regarded as military history, and it is to them that this high-sounding title is appropriated. Against this I feel bound to protest; every recorded military - experience is part of military history, and, therefore, military history includes all. But, I mention this confidentially at present, because one of the objects of this lecture is to put a certain amount of salt on the tails of some very wary military birds, and if I, prematurely, let out that these experiences are the same thing as military history, those same birds will spread their wings and $n y$ off before the operation is completed, just as the horse shied off from the flags with the death's heid and cross-bones.

Now, gentlemen, as regards utilising these experiences; and first, the purpose in view in utilising them. One purpose may be the increase of a man's knowledge generally; another, the mere satisfaction of a taste for historic knowledge; but one, and only one, shall I put before you in this 
lecture, namely, the increase of personal professional efficiency, the making the soldier a better soldier, the enabling him to do better the work which lies before him in the ficld to-clay and to-morrow. 'But since soldiers are of all ranks and all ages, the work before them is not the same for all. A general in utilising the experiences will need some of one class, a subaltern those of another class; moreover, the searchers after them differ in military knowledge; some of the experiences which to old soldiers $t$;e simpic and clear, are Hebrew to the young soldier; the elder men will know how to utilise them, the younger require instruction in their. use; how then, according to my view, these experiences should be utilised by officers at different times in their career, will now be submitted for your consideration and criticism; for merely to tell officers to utilise the experiences, or to "study military history," as the phrase runs, is like setting up before him a sign-post with the inscription: "Follow this road; it leads anywhere, and everywhere butnowhere."

To prepare himself for the work, which, when next the officer takes the field, he may have to carry out, must be the purpose for which he utilises these experiences. If a long and assured peace were before him, this purpose might not stand in the forefront; but as no one can rely on such a peace, this remains the first object.

Take him, therefore, at the outset of his career as a cadet at the R. MI. College. In the event of war breaking out, it is probable that all the cadets in the senior of the three terms would at once be commissioned; so that before he arrives at that term he should be well on in his preparation for the work which falls to a subaltern in the field, and even for the work which lies in a company command.

Many and various are the branches of military work in which, in and out of cloors, he has to be initiated during his residence of the College, and but little time, proportional to the importance of the subject, can be found for instruction in what may be called his tactical work. All the more need, therefore, to keep steadily in view the one purpose of the preparation of this company officer in embryo, and not to allow the instruction to go prematurely into flights beyond. It is often forgotten that many cadets, on joining the College have no notion of the real meaning of even such simple terms as battalion, squadron, battery, or brigade. Few but those who know cadets realise that the minds of many are, as regards military matters, like blank sheets of paper. The form the study of tactics should, and in fact does, take at the College is, first learning the theory of tactics, and then working out small problems on the ground-tactical exercises. But it is the arms in use on which all tactical operations depend; and therefore, this foundation, the nature and power of the arms in the hands of soldiers to-day, must be securely laid before proceeding to the erection of any superstructure in the form of a tactical exercise.

Do not the ficld-days at Aldershot, and manceuvres, show conclusively that it is the absence of realisation of this power of 
modern firearms, by even senior officers, that is the cause of the tactical operation being, as it sometimes is, a tactical anachronism?

In teaching any subject, we may commence with the inculcation of principles; but it is necessary that all teaching shall include illustrations of those principles; otherwise, although the principle may for a time lie on the surface of the brain, it may fade away, slip off, or not sink deep enough into it to fructify in the form of application to practice. Moreover, a principle is a bare abstraction, and the illustration is necessary to vivify the principle, and to explain its application to practical life. The illustration we use - the recorded military experiences of the past-is the instrument by which we fix securely the principle on the memory of the listener, and force it in deep enough to take root, and bring forth fruit in practical work. We have also, from time to time, to give to our pupils the mere dry facts called general statements, in which we may tell the cadet that the artillery to which his men will be exposed may be destructive at even 1,000 paces. We may tell him that an open, bare, gentle slope is, if possible, to be shunned by him when leading his half company, for it will prove to be for them a deadly charnel-house; we may tell him that if artillery dare to come into action against his men at even so great a distance as $7-800$ paces, it will be due to the bad shooting of his men if the battery does not pay a terrible penalty for its daring; but we cannot prove to them by actual experiment the truth of our statements. Moreover, a mere bald catalogue of distances is remembered for examination purposes, mainly like the arithmetic table which tells us that two pints make one quart, four quarts onc gallon.

But the recorded military experiences come to our aid in lieu of experiments, and they serve like pictures in a book to bring out more clcarly the meaning of the words and to excite interest in the minds of the readers. We should select for our future officer illustrations and experiences from that stratum of the mass in which the conditions and the powers of the arms employed, most closely approximate to those of the arms which will be in the hands of his men and of their foes. By diagrams drawn to scale, or by distances marked out on the ground, w: may bring home to his mind the destruction at Sedan of a team of artillery horses by Kraft's shells at a range of 4,000 paces; or Prussian guards, mounting in too close formations the glacis of St. Privat; or lastly; the Prussian batteries on the east of the Gravelotte ravine, and under fire at 700-800 yards distant, and losing all their officers, threequarters of their men, and more than their complement of horses.

And with this first impression, this impression we wish to convey to the cadet at an age when the mind is most receptive of inpressions, nothing counter must be allowed to interfere. Experiences blurring the power of the impression must be kept for the present out of sight, or far away in the background. I3ut eighteen months ago I happened to be present, when cadets were for the first time in their lives listening to the description of a real battle. In that battle one of the recorded military experieñces used was a battery of 78 guns coming into action at 6-700 yards distance with perfect safety against infantry armed 
with weapons constructed at a time when even percussion locks and rifled barrels were not yet known.

Surely, so far as preparing a cadct for company duties in the field to-day, the recorded military experiences of Cressy, Agincourt, Hastings, or perhaps Jericho, would have been as instructive; and certainly they would have been preferable, because the young mind will not confuse the experiences drawn from battles where the weapons are of different kinds altogether; whereas they may confuse those drawn from battles where the weapons used are nominally the same, and where the difference lies in the relative power of the weapons only. The experiences utilised at this stage, the introductory stage of instruction, must be only and solely those drawn from the uppermost stratum, that latest deposited. But on service, the subaltern will come across many incidents of war in which the power of the arms in use does not enter as a factor, and especially those connected with security duties and the stratagems of war, or those which show the value of high moral. There can be no possible objection to drawing for these on any stratum of experiences, however remote in time.

The preparation would be far from complete, were not the cadet, before he leaves the College, made acquainted with certain principles of warfare applicable to even the smallest encounter in which his half company may take part; and the teaching of these is simplicity itself, as simple as are the principles themselves. The mode of teaching them $I$ will show by giving that of three of the principles. Those of my hearers who have been present at any of my narrative lectures on the war of 1870 , or that on the "Fog of War," will remember the many square yards of paper I covered with diagrams, in order to render the subject of the lectures clear and understandable; and, therefore, I am sure they will acquit me of laziness if, on this occasion, - I substitute for diagrams of that kind the blackboard and chalk. Endless paper covered with a network of spiderweb lines, small red or black circles to mark places, and stencil-plated names would have, no doubt, added dignity to the exposition of the principles to be illustrated by them; but for practical purposes the blackboard and chalk do just as well, in fact better, as they are consistent with the simplicity of the principles.

No. 1.-A is a party of 10 cadets. $B$ and $C$ are hostile forces each of 7 cadets, advancing in the direction shown by the arrows. $A$ is nearer to $B$ and also to $\mathrm{C}$ than these two are to each other. I remark to $\mathrm{A}$, the 10 cadets, that if they await the arrival of both $B$ and $C$ they will be attacked by 14 cadets. I remind $A$ that they are stronger than $B$ or $C$ taken singly, and $I$ ask $A$ how they purpose to act so as to beat the allied foes. Nearly all the young men who enter Sandhurst by the competitive examination possess a certain amount of intelligence and common sense, so I do not doubt that they would at once say that they will go for the 7 cadets $B$ or $C$ and thrash them, and then turn on the 7 others and repeat the process. They might, however, hesitate to give an answer at once, believing, on account of the apparently simple character of the problem, that it was one of the examination-conundrum order, and of 


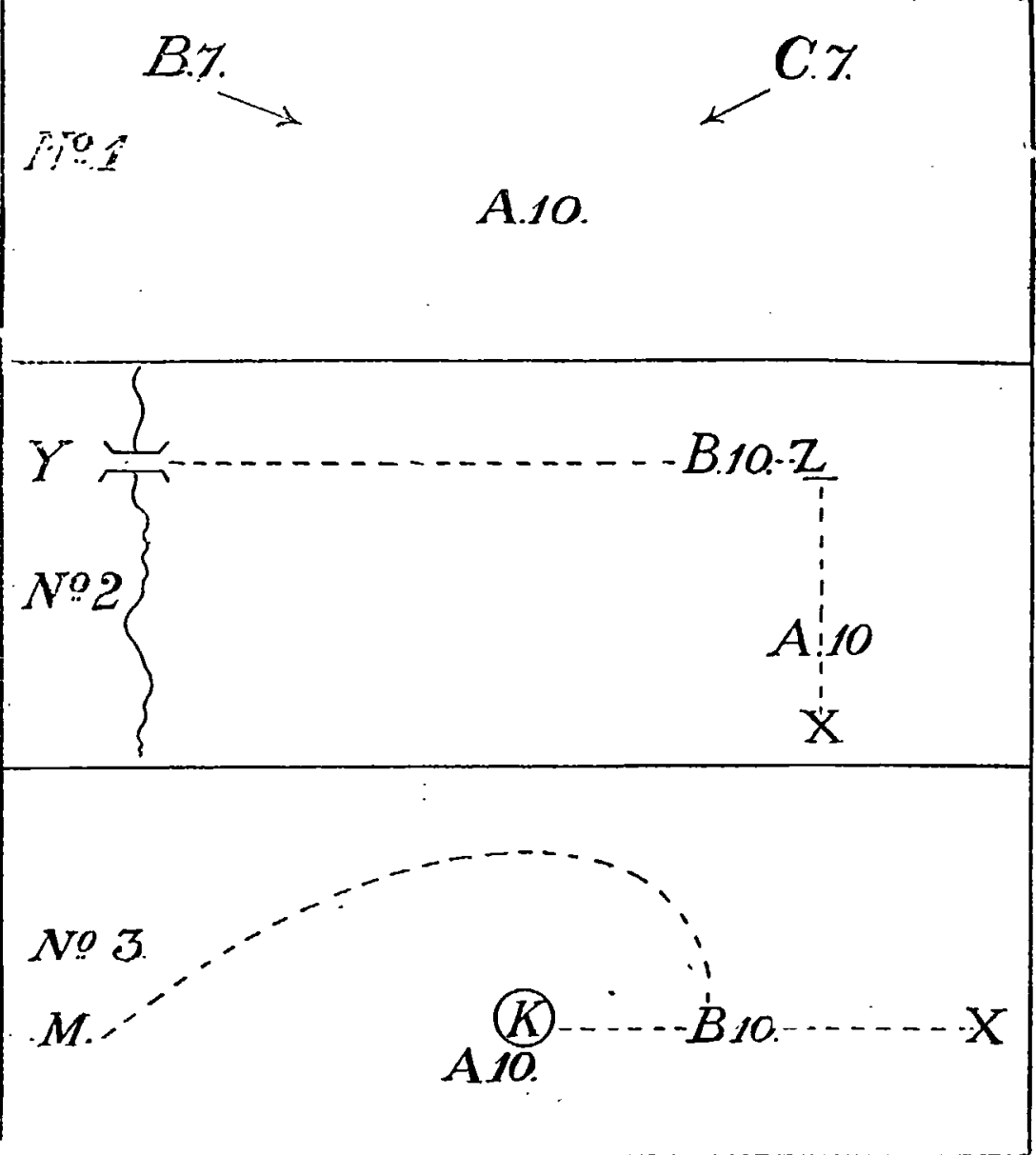

the class of which an example may be found in: "Why does a miller wear a white hat?"

No. 2.-10 cadets $A$ are advancing from $X$ to $Z, 10$ cadets $B$ are advancing from $Y$ to $Z$ by roads at right angles to each other; the road by which $B$ have come is the only one over the river shown on the board. The dinners are to be ready at $\mathrm{X}$ and $\mathrm{Y}$ after the fight. When $B$ sights $A$, they turn to the right and face $A$. I now put to the 20 cadets the following question: "Which side, if beaten in the fight, has the least chance of getting its dinner?" Result of question-a general impression that "teacher" is "pulling their legs."

No. 3.-After a light breakfast, 10 cadets $A$ go out from $X$ to hold the knoll $K$, leaving orders for lunch and dinner to be sent from $X$ to $K$ at 1 p.m., and 7 p.m. Neanwhile, 10 cadets $B$ go out from $M$, also after breakfast, to get $\mathrm{A}$ off the knoll. Each cadet of this party has a full -haversack of food and drink. B steals out of sight round the knoll, and, at about 12.30, when $A$, getting hungry is looking towards $X$ for the men bringing the lunch, he sees B 10 cadets come between the knoll and $\mathrm{X}$, 
and sit down and commence eating theirs. You will observe that each party now finds his opponent between themselves and their respective bases-I apologise, I mean kitchens. I think that by the time $B$ have finished lunch and have lighted their cigarettes, the meanest intelligence among the A party, acted on by the crying demands of empty stomachs, will have been awakened to the discovery, of which of the two parties is in the least pleasant situation owing to the enemy being upon the line between themselves and their kitchens-I apologise, i mean their bases.

Three or four additional argumenta ad homines, and of a similar character, but with which I will not occupy your time, would be given them, and then I should tell them that although I had explained to them these principles as guides to leading companies or half companies, yet they must remember that when Frederick or Napoleon moved their armies in great campaigns, it was these same principles they tried to follow, and no others. Perhaps one of the party would be incredulous on the subject, and would tell me that his elder brother, who was cramming for the Staff College, had told him that he was learning how generals had moved their armies, and that the principles they followed were called by a very big name, the "eternal principles of strategy." and that he was about to buy a thick quarto book in a red cover to learn what they were. $\mathrm{MI}$ y reply would be, that I was not responsible for his brother's outlay of money, judicious or injudicious, but that if the elder brother's object in buying the book was to find out what the principles of strategy are, he might spare his purse, and save much time by reading the notes of his younger brother on the little tactical exercises we had just carried out, for the principles were identical, no matter by what name called:

Initiated into the art of war in the manner I have described, the cadet leaves Sandhurst thoroughly prepared for his work as a company officer, and with the theory of war secured in his memory by the experiences recounted to him, and most applicable to the fighting of to-day; and I think that most officers commanding battalions or companies would regard such a recruit as having been very sensibly prepared for the work which he may have to carry out in the field under their orders.

I do not, however, venture to claim for him the high position of military historian and military critic, to which the cadets, the soldiers of barely one year's standing, and many of them not out of their 'teens, now justly hold. No cadet taught on the system here adrocated could have obtained many marks in reply to the questions given at the R. MI. College last December in a paper headed Military History. And my reason for bringing this -particular examination paper to your notice is that, in my opinion, it affords an excellent illustration of the different way in which the subject of my lecture is regarded, when it is treated as the study of military history, instead of being treated as the utilising for practical purposes the recorded military experiences of the past.

Of the three questions, one ran as follows:- "Describe, shortly, the position occupied by Wellington's army at the battle of Waterloo, pointing out its strong and its weak features." (50 marks.) For fear you may 
have forgotten your dates, I must remind you that the date of this battle is 1815. Of course; so far as rendering these cadets efficient subalterns in the field, and training them how to detect the weak and strong points of a position on a battle-field of 1897 , a similar question on the position occupied by James' army at the battle of Sedgemoor, and so clearly and graphically described by the present Commander-in-Chief in his "Iife of Marlborough," would have done equally as well. But a cadet taught as advocated in this lecture would have been better able to gain marks in a question as to the strong and weak points of positions where modern firearms are used in 1897 , for he would have learnt at least about one expressly chosen by a general, because it was better suited than was an alternative position for the full development of the power of the arms in use in 1870 by his troops; it was the position taken up by General von der Tann at Coulmiers, on the 9th November, 1870. As to advanced posts, he would not possess the antiquarian knowledge of the advantages and disadvantages of a La Haye Sainte in advance of a firing line in 1815. But he would show himself at home in this matter, at all events, as it stood in 1870, fifty-five years nearer his own time-because he would have learnt not only about St. Hubert and Champenoise, but also about the little hamlet of Les Cotelles on the battle-ficld of Beaune la Rolande-localities all in advance of a line armed with firearms comparntively little dissimilar from those of to-day.

Another question given to the Sandhurst veterans ran as follows :"Q. 2. Criticise Napoleon's own movements and the disposition he made on the 17th June-the day after Ligny and Quatre Bras." (50 marks.) To this my cadet would have replied: "Being only a cadet, I find I cannot spot the mistakes made by the Aldershot generals at the field-days at Barossa and on Turf Hill, so my instructors do not ask me to criticise the operations of these officers. With regard to the general named in question 2, I should have been very happy to put down and give as my opinions those of our instructor, if he had told me what they were; but as he has not done so I cannot answer the question." Nay not the comment on this class of question be almost in Shakespeare's words :-

$$
\text { "Imperious Cresar, dead and turned to clay }
$$

Mlight stop a hole to keep the winds away."

Or slightly paraphrasing another passage: "To what base uses may we come, Mr. Examiner Horatio. Why may not imagination trace the convolutions of the great brain of Napoleon, till we find it stopping the bunghole in the memory of a second-term cadet at the Royal Military College?"

Do not credit me in portraying thus this branch of instruction under the Department of Military Education, with which I have had the good fortune to be so long connected, with any such foolish desire as to merely make fun of the instruction, and to hold it up to ridicule. But, gentlemen, it is only two or three years ago that the Board of Visitors to the Royal Military College succeeded in re-introducing into that establishment a so-called study of military history, of which this examination paper is the most recent outcome; and I know that at the present moment efforts 
are being made, in certain influential quarters, to induce the Army authorities and the Military Education Department to sanction an extension of this study on the same lines.

I have, therefore, no hesitation in saying, that, in my opinion, this method of utilising for the youngest soldiers of our Army the recorded military experiences of the past is out of date, and can only be regarded as obsolete, and in disaccord with that spirit of practical military teaching which is one of the most marked features of the age of military training in which we live. ${ }^{1}$

And now to the utilisation of experiences by the cadets when they become officers. We may consider these officers as bifurcating into two sets: one of officers who determine to throw study to the winds until any promotion examination begins to cloud their horizon; the other of officers who, after a good long spell of rest-it may be for two or three years or more, spent in the wholesome enjoyment of young life-pick up again the dropped threads of professional study. The case of each set of officers must be considered separately; to the former, the non-reading officers, I will first offer counsel.

I do not ask you, the non-reading officers, to study military history, of which occupation you are wont to speak with supreme contempt, as fit only for bookworms and feather-bed soldiers. I wish, however, to bring to your notice the existence of a vast mass of recorded military incidents, similar to those which would happen in any war of to-day or to-morrow; and showing you how soldiers have behaved and acted in situations precisely similar to those in which you will find yourselves on service in the field. They come before you, it is true, in most objectionable shape in the form of the horrid black marks at which you so much dislike to look; but this defect can hardly be got over. But suppose for a few moments that you were voluntarily to undertake the command of a fire brigade, liable to be called out for duty at any moment. Would you not, without delay, get hold of some of the old firemen, and ask them to tell you about putting out fires? And if no call on you was made for some little time, would you not as soon as possible read up the most recent reports by your predecessor on the outbreaks of fire and the mode in which they were extinguished? If you refused to avail yourself of these experiences, is it not probable that at the first outbreak of fire with which you had to deal you might altogether fail to extinguish the fire, or that in extinguishing it you would sacrifice the lives of two or three firemen, where, under an experienced commander, only one need have been lost?

So, as you may at any moment have to answer to the military battle-field call, and exercise that command which you voluntarily undertook when you accepted a commission, and as you will then find yourself in a similar responsible situation, is it not reasonable that you should, in order to do your work

1 I have been informed that my remarks on this examination paper may read as somewhat like an attack on the examiner who set it. I disclain any such intention. The questions were of the ordinary type, and were strictly orthodox.L. A. $\mathrm{H}$. 
better and not to unnecessarily sacrifice your men's lives, take the trouble to learn from the recorded experiences of older soldiers how they acted in similar difficultics? Don't let false pride or false amour-propre lead you to think there is anything infra dig. in not trusting absolutely to, and relying implicitly and solely on the aid of the contents of your own skulls, however valuable those contents may be. 'There was once a man who suddenly had to lead an army on a campaign; but as soon as he found out what he had to do, he did not sit down and study military history; although I latcly heard one of my friends say that he did. He knew that another leader had carried out a campaign over this same tract of country not so very long before, and therefore he at once asked the -military authorities of his country to send him every available record of what his predecessor had done, so that he might draw on his experiences and profit by them. That man you may not think much of, because I have told you that the faults of his application of the principles of strategy are so transparent, that even cadets at Sandhurst are considered competent to expose them; but he was a bigger man than all those 350 budding young von Moltkes put together-he was Napoleon.

I fully admit that the experiences useful to you are not in all cases easy to obtain, but many lie close at hand. I only now ask you, do you assent to the proposition that they are of value to you as practical soldiers for increasing your vorth and power as practical soldiers, and for enabling you to do your duty in the ficld? You are; I fear, in a dilemma: for if you deny it you lay yourself open to the suspicion that the price you would charge for yourselves, skulls and contents included, per pound in the open market is somewhat exorbitant; if you assent, the reasonable corollary is that you ought to do your best to get hold of these experiences, and the final result is that the salt is firmly placed upon your tails. With it there I bid you good-bye, and ask you peacefully: to slumber during the rest of this lecture which, as it is about the study of military history, neither concerns nor interests you, though it may both concern: and interest some of your brother officers.

Returning to the course to be taken by the officers willing to read, the immediate purpose before them is, it must be remembered, to prepare themselves for the work of to-day, that in which they will have to take part, the work they will have to carry out in the field. But they are also ambitious to rise in their profession, and they wish to learn more about it. A knowledge of the higher tactics and of strategy they desire to acquire. As regards the former, they will gain fresh knowledge by continuing to draw on the recorded experiences, and this they can do safely, guarded as they are by the truth already indelibly impressed on their minds that tactics depend for practical purposes on the arms in use.

As regards strategy, they, long ago, learnt what the principles of strategy are; what they want to learn is how to apply these principles to practice in the closing years of the nineteenth century. Now, any application of these principles to practice is regulated in the first instance by what may be called the military mechanical conditions existing at the time of this application. A general who is entrusted with the conduct of a 
campaign is griven for the purpose of carrying it out an instrument known as an army, and he is told that the instrument is to be worked ainong certain physical surroundings known as the theatre of war; the army and the theatre of war are the military mechanical conditions. The particular way in which he will conduct the campaign depends, therefore, on the nature of the particular instrument or army he has.to use, and on the physical-surroundings, the theatre of war, amidst which it is to be worked. The genius of the general shows itself, not in the selecting some particular application of the principles of strategy suited merely to the relative positions of the hostile forces, but in selecting that application which is best, not only with regard to these positions, but also which is best suited to the working of his instrument amidst certain surroundings. But although the instrument and the surroundings may each bear the same name for hundreds of years, e.g., the French Army, the valley of the Danube; yet each varies in itself so much at different periods of history, that the mode of carrying out an operation at one time, e.g., 1650 A.D., may be quite unsuitable at another time, e.r., 1900 A.D. Consequently, before studying military problems of to-day involving strategy, the student must ascertain what is the particular army of to-day, the instrument in the hands of the general, and what the particular theatre of war in which the general has to work it is like. I will assume tiat the student selects the French Airmy as the instrument, and the region between the Rhine and Paris as the surroundings. He proceeds to ascertain what the French Army of 1897 is; and every detail of this tract of country in 1897 also. He may then select another instrument to put in the hands of a hostile general, say the German Army of 1897 ; and having learnt all about this instrument, he may, if he chose to do so, work out the operations involved in an advance of the Germans from the Rhine on Paris. But, being perhaps somewhat doubtful of his ability to. deal satisfactorily with so big a problem, and remembering that of a similar campaign in 1814 a high authority" has written, "So various are the lessons conveyed by this campaign, that the reader who has mastered it must be competent to investigate almost any problem which strategy can offer," he may, in order to get a line for the solution of the problem in 1897 , draw on the recorded military experiences of the past for the example given him in 1814, by Napoleon, Blücher, and the other leaders in the campaign of that year. But he will not have examined these experiences to any extent before he will find that the instruments of 1814 differed radically from those of to-day and to-morrow in almost every respect, in composition and organisation, in their wants and needs, in the mode in which those wants and needs were met; he will find that the mobility of the armies in 1897 is almost lightning speed compared with those of 1814; he will find that leaders of armies, or of portions of armies, however far apart in 1897 , are in close personal communication with each other and combine their movements with perfect ease; whereas in 1814, they were hours or days apart. If he turns to the surroundings, he will find the physical features such as hill ranges or large rivers, which were obstacles to progress in 1814 , tunnelled through or bridged over so as to vol. XLI. 
cease to be obstacles at all ; bad roads replaced by good ones, good ones increased in number, the methods of locomotion transformed. The world in 1814 seems to him so different from that of $189 \pi$, that he regards it for military operations of to-day, 1897 , almost as prehistoric; and then. someone tells him of a campaign carried out not long ago in this same theatre of war, where, what I have denominated the mechanical conditions, the armies and the theatre of war, were almost identical with those of to-day. $\mathrm{He}$ draws forth this experience from the recently deposited stratum in which it lies. The label it bears at first checks him, for it runs " Nade in Germany." He would prefer a home-made article, so he searches into the varjous underlying strata, but not a single home-made strategical experience subsequent to the prehistoric age can he find; so, at the risk of being thought to be deficient in patriotism and gone "German mad," he makes the best of a bad job. Needs must when the devil drives; the gentleman with the cloven hoof drives him to the Franco-German war of 1870 , where he soon finds he is living among armies similar, almost identical, to those of to-day, and moving among surroundings, railways, telegraphs, roads, railway tunnels, viaducts, and chaussées, the same which meet him wherever he turns in France, in 1897. But does he find there any of the examples of strategy that he wants? I think he will find a few. Von der Tann at Coulmiers, von Werder on the Lisaine, von Goeben at St. Quentin, forcer to form front to a flank under modern conditions, just as was Mack when facing Moreau under prehistoric conditions; Bazaine and Prince Frederick Charles at Vionville both forming front to a flank, as their forefathers are said to have done in old time at Jena; the advance on Le MIans from Chartres and Orleans is similar to that which the Archduke Charles opposed in the basin of the Danube; Gravelotte shows an army placing itself across its enemy's communications, as does $\mathrm{Ulm}$, in 1805 . The time-honoured and hackneyed salient and re-entering frontier of Noreau in 1800 , is replaced by that of von Moltke in 1870 .

Gentlemen, with which study ought the officer, in your opinion, to begin: that of the latest, 1870, or that of the earlier period, 1814? Remember, that he is reading and studying, not for mere personal interest, but to make himself a better soldier of to-day and to-morrow.

Let me make a personal question of the matter. No doubt the locomotive drivers of George Stephenson's day managed fairly to avoid railway smashes, and to keep tolerably good time with their trains. Gentlemen, if in six months' time, you all found yourselves in the Flying Dutchman, Scotchınan, or Irishman, with Colonel Lonsdale Hale about to act as driver, what would your feelings be, and would there not be a rush for accident insurance tickets, if $I$, putting $m g$ head into each compartment in turn, informed its occupants that they need be under no alarm for their safety, for I had been studying railways and their working ever since we parted this evening, and, knowing the principles of their working to be "eternal," it had not seemed to me to be of much importance at which end of the recorded railway experiences of the past I began, so I had employed the six months' interval in reading all about the life and times of George Stephenson; that I had spent many hours in 
the South Kensington Muscum, where I had first mastered the driving of a locomotive built in 1812-13-the era of Moscow and Lcipsic, by-the-byethe first which ran with smonth wheels on smooth rails, and known as "Puffing Billy"; then continuing my studies strictly in chronological sequence, I had taken full notes on another locomotive there, called the "Rocket," which in a prize competition in $1829^{\circ}$ gained the prize of $E^{500}$, and ran at the express speed of twenty-nine miles an hour; but I found that both the "Rocket" and poor old "Puffing Billy" had been consigned to the bourne of mechanical fossils in 1862-two years, by-thebye, before the appearance of the infantry breech-loader as the foundation of modern tactics for the next thirty years. I should then have to tell you that, owing to the intensity of my prehistoric studies, I had been unable to avail myself of repeated invitations of drives and talk given me by a London and North-Western driver since I had undertaken to drive this particular express; but that when I next came across him, possibly in a collision that night, $I$ intend to learn how to drive trains under a system of signalling known, I believe, as the Block System, and to examine a queerlooking arrangement on this train, and called a vacuum brake, both of which are at present Double-Dutch to me; and I am resolved to do this in spite of a warning I have had to the contrary, to shut my eyes to both of them, because report says that they have been " made in Germany."

For practical soldiers, with no assured length of time for study before they may have to utilise in the field the experiences of the past, there is only one way to study and draw on these experiences. It is the way I have applied to one campaign in one theatre of war, and which is equally applicable to all. 'Read military history, read the applications of the principles of strategy, read the development of the art of war, draw on the recorded military experiences of the past-not, as children, we read our Pinnock or our Goldsmith forwards from Alfred the Great to Victoria the Greater, but backwards from Victoria the Greater to Alfred the Great. Read military history, its campaigns, its strategy, its battles, its tactics, backwards-not forwards.

But most dangerous would it be, if a student, possessing a knowledge of only the mechanical conditions of a campaign, the army and the theatre of war, accepted the examples of the leaders of the past as a guide for their own action in the future. There is yet to be sought out in any and every campaign a factor which is most influential in determining the mode in which any principle of strategy shall be applied, and even, perhaps, whether its application is practicable at all. That factor is the moral, actual and relative of the instruments, the opposing forces, the condition of the personnel of each; the characteristics, special and general, of led and leaders alike. Ignore this factor, and we miss the clue to the successes of the First Napoleon, to the disasters of the Third Napoleon, to the successes of Lee and Stonewall Jackson, to the disasters of Pope and McClellan. Ignore not only this factor, but also the mechanical conditions as well, and then strategy resembles a game of chess, only in all the theatres of war being as identical as are all chessboards; here the resemblance.ceases, for all the war pieces, whether kings, queens, or pawns, are 
of equal value, not mercly in one, but in all campaigns; and those of 1897 A.D. are those of 1897 b.C. Ignore all these vital differences and distinctions; then if because we have.read that in time past some great master of the art, by adopting a certain gambit speedily gave check to his adversary, we determine to play our game in the same way, it will not be due to good strategy, but to luck and good fortune only, if we find that the move sanctioned by authority does not land us in a situation where checkmate to ourselves is the immediate and dire consequence.

It is the almost total neglect of the personal conditions, and the comparatively small notice taken of the mechanical conditions, that makes me object so strongly to the use of Hamley"s "Operations of War" as a book for beginners. The human element enters into it hardly at all. The references to the nature of the Army, the instrument ; to the surroundings, the theatre of war; and to the personal characteristics are very limited, so that the study of the campaigns becomes a mere monotonous pursuit of chessmen pieces all of the same value over chessboards; a deadly dull game of hide and scek with mere statuettes labelled Ncy, Napolcon, Radetsky, Wellington, Archduke Charles, amidst a labyrinth of black lines, and a classically chosen and classically arranged large collection of the horrid black marks called words. If you doubt me, read Hamley's account of the campaign of Eckmuihl. To anyone, who already really knows that campaign, the account may be interesting, intelligible, and for ought I know profitable; but for those who do not, it is but dry bread, I may almost say ships' biscuit, and, to my mind; as unnutritive and indigestible.

As regards officers quartered in India, it must be remembered that warfare in India has its own special charácteristics; and the military his tory and the recorded military experiences of warfare in that country deal with a branch of the practice of the art of war vast in size and extending over near a century and a half of time. It would be well, therefore, for these oficers to devote themselves to acquiring bnowledge solely with regard to Indian warfare in the past, and not to turn to warfare outside India until they have thoroughly prepared themselves for the work before them in that province of the Empire. Work, however, backwards in time, and whilst thus working forget Waterloo; and to show my perfect - impartiality, I say, forget Gravelotte also.

The main characteristic of our small irregular warfare is, that it varies not so much according to the dates of campaigns, as to the locality of each; and therefore a knowledge of how warfare has been conducted successfully in one locality, is no safe guide as to its proper conduct in another. The records are not very extensive; and an officer ordered to join a force about to carry on an operation in any of these expeditions will find plenty of time to study, during his voyage to the theatre of war, the recorded military experiences relating to wars previously carried on there. But let him here also read backwards.

The study of campaigns, to be profitable, is very laborious work, so laborious that only $a$ few gifted soldiers-and I own I envy them-can master many of them. But there are few officers who by working hard 
cannot master some one campaign. And the mastery, the complete mastery, of a single campaign supplies us with a touchstone, which will enable us to form a fair estimate of the practical value of the history of any campaign furnished to us by others. Knowing what one campaign really is, we know that there are, in connection with the application of strategical principles, certain points and matters with which every military historian, knowing his subject, must deal. If we find these matters ignored, or the points missed or either treated superficially, or as of no consequence, then we may put the book on one side, and rest assured that though our would-be teacher may not be the unpleasantly-voiced quadruped in the lion's skin, he certainly is but a mere, and, perhaps, but poorly-informed narrator, attempting to impose upon us, and only masquerading in the garb and mantle of the military historian; he is no teacher for us.

Grounded thoroughly in one campaign, and thus provided with the touchstone, officers who desire to learn yet more of the higher leading of war, may draw, with profit to themselves and with increase of their own professional capacity, on any recorded military experience of the past, no matter how deep down the stratum in which it lies buried in the deposits of the past; but let him, if ever tempted to pronounce judgments on the conduct of leaders, remember that whilst criticism of this kind is a very simple matter, within the reach of any charlatan, it is only when such criticism has been preceded by great personal labour in collecting facts, and by the exercise of sound judgment in sorting them out and weighing them, that the criticisms themselves are worth more than the ink with which they are written, the breath used for speaking them.

Gentlemen, I hope that I have succeeded in making tolerably clear to you the three main and cardinal principles which I advocate for the study of military history by the officers of the British Anny. The first is that, primarily, that study should be purely utilitarian-that is, that it should be useful to the officer in the field; the second is, that it should be suited to the rank he holds, and to the work which lies immediately before him in the field; the third is, that the study should run chronologically backwards-not forwards. These three principles I submit for consideration and criticism.

And now, in conclusion, a few words to those officers who form the body of military instructors of the Army, whether professors, instructors, or D.A.A.G.'s for Instruction. Although myself retired from the Active List, I think I may, without any presumption, consider myself as still one of you ; and as I am now in my thirty-sixth year of continuous work as an instructor in military art, I fear I am your doyen-I stand first on your list of seniority. Permit me, then, to offer you one result of that long experience.

To what extent the average British officer will study his profession, or whether he will study it at all, is, I think, determined to no small extent by how he regards us, how we regard him, and how, when for instructional purposes we come in contact with him, we put this study before him. I detest the names by which we are known-Professors, Instructors, 
D.A.A.G.'s for Instruction-not because they designate a branch of work looked down upon by the Army at large, for that day is gone by; ; but the evil of it is that it makes teachers one caste, taught another; and it stands in the way of camaraderie and of the relation between the two classes being that which ought to exist. We must endeavour to make the officer understand that the sole difference between him and us lies in the fact that, somehow or other, certain knowledge of great value to soldiers on service in the field happens to be in our possession, but not in his; :and this knowledge we are ready and desirous to share with him, so that he also may profit by it and have it ready for use in the field. But we must take especial pains to put before him this knowledge in its most practical shape and aspect; and, also, so far as we can, we must suit the physic not only to the wants of the patient, but also so far as possible to suit his tastes also. We shall have to allmit to him that a certain amount of reading is necessary, but do not let us alarm him even by a glance at any fairly-stocked military library we may possess. But from it let us take and offer to him the lightest literature it contains, say, "The Badge of Courage," or some book christened. with some light and not alarming title. 'The amount of valuable professional information and knowledge to be gathered from the lighter literature of war is great indeed. If there are in our possession a letter or two from one of our own comrades, telling "is how perhaps only six weeks ago he, it may be a subaltern on piquet in Burmah, had repulsed an attack on the outposts, let us give him that to read and study to his profit. It is a recorded military experience of the past, it is military history as much as is Napier, Duquet, or von der Goltz. To find books of this kind for officers who read French or German is easy enough. I name one only, von Tanera's " Recollections of a Galloper." But for officers not linguists there is a sad deficiency; and were I some ten years younger I should be tempted to initiate the supply of works to make it good. But still they exist, sometimes as translations, and among them I name as an instance the chatty, chcery letters of Kraft on infantry and artillery:

This kind of reading will act as a stimulant, as a tonic to the literary appetite of the non-reading officers, and by degrees they may be led on to higher flights; and, on the strength of having found the first morsels of horrid black marks really palatable, they will, after having dallied with the entries on the table of military history determine, perhaps, to remain there for the next course, and will go in boldly for a slice of the first joint, even if it be a campaign of the past, and no matter how tough or difficult to digest it may appear to be from outside inspection. And to afford them encouragement, let us on our side endeavour to throw life into the subject; let us clothe with flesh, blood, muscles, and nerves the dry bones of strategy, so that they cease their appalling rattle; let us vivify the literary prescriptions of the drill-books with the inspiring recorded experiences of our soldier forefathers of the past. Finally, for the ideas of teachers and taught, teaching and learning, let us substitute that of brother officers giving to and recciving from each other useful practical knowledge; and in no branch of our work is this more easy than in that 
which I have brought before you to-day, "The Professional Study of Military History."

Lieut.-Colonel G. F. R. Hendersox (York and Lancashire Regiment, Professor of Military Art and History, Staff College):-There are a few points in this interesting lecture on which $I$ should like to make a few remarks, not so much by way of objection, as of representing the other side of the question-a side which Colonel Hale has of course considered, but has not had time to touch upon. The first of these points has reference to the study of strategy. Colonel Hale has told us that the principles of strategy are few in number, and that they can be taught by a series of familiar illustrations. But he has also suggested that their application is by no means so easy. I need hardly say, in common, I am sure, with the rest of the audience, that I thoroughly agree with him. You might tell a boy that the great secret of success in cricket is to play with a straight bat; but I do not think the mere knowledge of that principle would enable hin to make a hundred runs at Lord's. To compass that achievement he must see good men play and have plenty of practice. The same with strategy. A mere acquaintance with principles is insufficient. I may presume, without affectation, that I have more experience of teaching strategy than any officer here present, except Colonel Hale himself, and the outcome of my experience is that officers may know the principles of strategy by heart, and yet when it comes to application, that is when they are asked to work out a plan of operations for the attack or defence of a certain territory, they very often fail allogether. Directly they are face to face with a concrete situation they ignore principles altogether, and put on one'side every single rule that has ever been laid down on the art of war. The reason is that strategy, to tny mind, is a far more difficult art to master than tactics, simple as it may appear; and it is therefore of the very greatest importance that it should be studied in the right way. It certainly is absolutely essential that students of strategy-and these include all officers who aspire to command in the field-should thoroughly comprehend the changes which have been brought about by steam and the telegraph; while the part played by physical obstacles, by roads, rivers, and bridges, can never be underrated. But at the same time, it is to be remembered that means of movement and communication are not the only factors in a strategical problem. The "eterral principles," at which Colonel Hale seems rather to scoff, have still to be applied. I may quote General Sherman, who had a great deal to do with railways and telegraphs. He brought his manœuvres to a successful conclusion principally by the effective use he made of modern inventions; and yet he tells us in his Memoirs that the principles of strategy on which he acted in his march through Georgia were exactly the same as those which were applied by Hannibal. To apply these principles correctly something more is needed than the correct manipulation of the railways and the telegraph. The great aim of strategy must always be the same, i.e., to concentrate the superior force, moral and physical, on the field of battle, and to do this a general must outmanouvre, outwit, and deceive his antagonist, and thus bring his full strength against a weak and vulnerable point. I would ask the lecturer, with all due deference tohis thirty-six years of instruction-years for which the British Army has good reason to thank him-if he is quite certain that the campaign of 1870 is the best guide for British-not German-officers as to how this may be done. I do not wish for a moment to assert that the çampaign is not exceedingly instructive; but von Moltke is not the only master of the art of war. Even his most enthusiastic admirers do not rank him as greater than Wellington, than Napoleon, or than Lee, and the art of out-mancuvring; outwitting, and deceiving the enemy is not a mere matter of mechanical means. In fact, I cannot quite see that in the campaign of 1870, from the time the concentration of the German Army was effected up to the battle of Sedan, that the railways and the telegraph, improved roads and more numerous bridges, played a conspicuously important part. The railways certainly 
facilitated to some degree, but to some degree only, the supply of the enormous hosts which crossed the Rhine; and the telegraph appears to have reduced the risk which was considered by Napolcon, Wellington, and Lee, so great a danger of dispersion. But railways and telegraphs did not affect in any marked degree, so far as I can see, the application of strategical principles. "The mancuvres before Gravelotte, for instance, of the 1 lst and 2nd Armies under Moltke himself were Napoleonic in conception, and executed in exactly the same manner, and certainly (notwithstanding the lightning mobility that Colonel Hale has referred to) with no greater rapidity than Napoleon would have executed them; and the same may be said of the mancuvres before Sedan. In fact, the French were outwitted and out-manceuvred, not because the Germans had railways and the telegraph, but because von Moltke used his cavalry as did Napoleon, because his troops could march like Napolcon's, because, like Napoleon's, they subsisted to a great degree on the country; and, lastly, and this is to the point, because Moltke had learnt to apply strategical principles from the campaigns of Napoleon and of Frederich. Moreover, the 1870 campaign, as a guide to the application of strategical principles, is always upen to the objection that von Moltke's manceuves, like those of the other German generals, could hardly fail to be successful against an enemy so inferior in numbers, so indifferently organised, and so deplorably commanded as the French. I will cite the example of Stonewall Jackson, who was undoubtedly one of the most brilliant of modern soldiers and strategists. He commanded in a theatre of war which possessed both railways and the telegraph, and of both these auxiliaries he made most effective use; but he always carried Napoleon's maxims in his haversack. Colonel Hale has told us that, with the telegraph, Armies that are dispersed or separated can now combine together with absolute certainty. I had yesterday put into my hands a paper showing the number of times in which, during the 1870 campaign, the telegraph had proved a most uncertain instrument of war. Even at the very beginning, on the night before the first battle, the telegraph broke down altogether. As Colonel Hale will remember, there was only a distance of sixty miles between the headquarters of the German Army and the headquarters of the lst Army, yet that most important telegram took twenty-four hours to traverse those sixty miles! In my own opinion the war of 1870-7l is not the best suited for the study of the influence of railways and the telegraph. For English soldiers it seems that Moltke's campaigns, as regards their auxiliaries, are far less useful than those of the Civil War in America, or than the Egyptian campaign of 1S82; and so far as regards the application of strategical principles, the campaigns of Wellington have, 1 think, a very special value. In the American, the Egyptian, and the Peninsular campaigns the sea-power played a most important part, and a knowledge of how strategy is affected by the sea-power is likely to be of more practical benefit to English commanders than a study of railways and the telegraph. Again, if, as the lecturer says, an officer studies military history in order to prepare himself for the work of to-day or to-morrow, it may be questioned whether it would not be better, if his lime is limited, to confine his attention to campaigns which have been fought on theatres of war of the saine charactet as those on which he may have to fight hinself. Military operations in South Africa, or in the outlying.dependencies of our own or other people's Empires, have very little in common with the campaign of 1870 ; but they have very much in common with the campaigns in America, or with Wellington's campaigns in Spain and Portugal. And there are yet other reasons why Wellington's campaigns have a special value. Strategy is not merely a question of out-manceuvring the enemy, especially English strategy: In the first place, English strategy has its political side, for the soldier is never independent of the Government; and it has its diplomatic side, for we are often assisted by allies; and, above all, organisation and administrative services have often to be improvised on the spot, with insufficient means, inexperienced officials, and auxiliary troops. Within the last twelve months four comparatively 
junior officers have found themselves in independent commands of important expeditions, and I am perfectly certain that if cither Lieut.-Colonel Plumer, or Liẹt.Colonel Alderson, or Licut.-Culonel Hamilton, or Major Arnold were asked, they would say that a knowledge of the rough-and-ready methods of the Peninsula or of America would have been far more useful to them than the most intimate acquaintance with the operations of von Moltke. I may add that I can endorse to a very great extent the lecturer's criticism on the "Operations of War," as a textbook of strategy. It was for many years the sole text-book for the Staff College entrance examination: but it was discontinued, I think, in 1894. Since then officers competing have had to rely on their knowledge and observation; and the papers set, so far as I can judge, have aimed rather at discovering the measure of their capacity for hard thinking, and of their ability to apply principles to concrete cases, than the mere strength and accuracy of their memory. This has been a move in the right direction, and the results which appear in the Staff College course have been most marked.

Lieut -Colonel Stssox C. PRatr (p.s.c., rétired pay, R.A.):-I cordially endorse the views laid down by the lecturer, and the Army at large should thank him for pinning us down to the utilitarianaspect of military studies. To-day, however, I merely want to refer to one point which the lecturer has raised, that is, the instruction in military history at Sandhurst. I venture to put in a plan for the Waterloo campaign. Colonel Hale has referred to the necessity of illustrating the minor operations of war, advance posts, artillery positions, etc., by means of the most recent incidents in the 1870 and subsequent campaigns. He points out that this should be done in the course of military history; but I wish to show that these matters are a!ready dealt with at Sandhurst. They have a most elaborate course of tacties; and I submit that all these incidents in modern warfare-and I think they should be the most modern incidents-must rightly be used as illustrations in a tactical. course. They have al so at Sandhurst an administrative course, in which the cadets are informed of the modern organisation and supply of Armies. These are points which Colonel Hale has alluded to as being of practical utility in the study of military history, and a certain amount of his arguments have been swept atway by the teaching of these subjects in separate courses at the Military College. With what object was the additional study instituted? I am not prepared to discuss whether it was a good or a bad measure, but there it is ; and we must look at the military history of a campaign as simply the frame-work into which the several incidents of modern warfare, illustrated in the tactical lectures may fit. It also gives the cadets an idea how a campaign as a whole is conducted. Above all, in dealing with young officers or cadets, the main object should be to interest them in the profession they are going to take up. To put it in a concrete form I would make a suggestion. Colonel Hale is one of the most admirable military lecturers that we have had; and if anybody can rivet the attention of an audience he will do so. Now, I would ask him to imagine himself in this hall faced by a hundred Sandhurst cadets, while lecturing on the Waterloo campaign. I venture to say that his remarks would be followed with the most vivid attention, and that the dropping of a pin might be heard in the room. At the close of the lecture, too, the cadets would come to him asking questions, and showing their great interest in the subject. The opening of the 1870 campaign, say up to the battle of Sedan, would .also rivet the attention of the students. But let us go a little further, and take - Colonel Hale's favourite campaigns on the Loire or the Lisaine, or in the north of France. I venture to say that even with a lecturer of his great ability a large :portion of the audience, after ten minutes, would be in a comatose condition.' In

1 This prediction is directly contrary to my personal experience, for I have imanaged to keep two large public school audiences wide-awake through the whole of "Coulmiers." The battles of the second period of the Franco-German war teem with incidents of interest to young soldiers, whilst Beaune-la-Rolande is simply dramatic.-L. A. H. 
a Military College we ought to have campaigns which are attractive to young students; and I ask, Can there be one which would appeal to a cadet more than the Waterloo campaign? Are we to send young officers into the Army to whom Napoleon and Wellington are mere names? Are we to send lads into the Navy to whom Trafalgar and Nelson have no meaning? I think Colonel Hale is rather unfair in suggesting that young officers cannot derive benefit from the older campatigns. To my mind, the diagram of the ten cadets and the seven cadets on the blackboard is really no more interesting than the multiplication table. I think if you can show a young officer how these same principles are worked out by large Armies in the field, they will be much more impressed on his mind than by drawing diagrams on the blackboard. Then, with regard to tactics, surely any good lecturer can give valuable information from the Waterloo campaign. It is not a mere question of distances. A great deal can be taught by way of contrast. Let a lecturer describe the battle of IVaterloo, and then show the cadets how the battle would have been fought under modern conditions. Let him describe a modern battle, and then refer back to Waterloo, and contrast the methods of fighting. This method of contrast is very taking to young students. You will remember that with the old temperance lecturers, one of the most vivid ways of bringing the subject to the attention of an audience was to bring forward "a terrible example," and exhibit him on the platform. I agree with Colonel Hale that military instruction should, as far as possible, be of the most modern type. I would not go back to the older campaigns of Napoleon, because you cannot sufficiently interest the students in them. Colonel Hale has given us an admirable and eloquent lecture; and the object of it apparently was to attack a little bantling at the Royal Military College of some eighteen months' standing. There is a big brother, within a mile, at the Staff College. Why, then, in taking the subject of military history did he not give us his ideas as to the course which has been long established at the Staff College?

Major C. B. MArNe, R.E. :-The point of view from which I wish to speak is the cadet stage of our Service, and also of a class of officer that Colonel Hale has not mentioned-the careless reading officer. On reading this lecture, I threw myself back to my àcademy days, where we had a very brilliant lecturer who used. to carry us away with his accounts of various campaigns. He gave us the Waterloo campaign as an illustration of older ideas and taclics, but he also gave us some account of the Franco-German war. When I left the Royal Military Academy it was with rather large views for a cadet (indeed one rather imagined oneself as capable of leading large units) until I came to Chatham, where I had the good fortune to come under Colonel Hale's instruction. He gave us the detailsof companies and battalions, and I at once felt that that was the instruction I really wanted at the academy. I remember Colonel Hale telling a story of an officer who went to the Zulu campaign, and who found that the system of outpoststaught by text-books was very different from the system used out there. That also was the first thing that struck me in going to the Afghan campaign, where there was a totally different state of affairs from what one had learnt in regard to large European campaigns. It was afterwards my fortune to be instructor in military subjects for seven years at the Royal Military College in Canada, where I was given a free hand to arrange my course. I had the cadets for three years, but for only two hours a week, during eight months in the year. The course I established for the first year was what Colonel Hale has referred to as the knowledge of the arms of the Service, upon which all tactical operations depend. I wished the young fellows to start with a knowledge of the actual facts connected with the various arms of the Service, as the very elements of their work. The second year I carried them on further in tactical work, in order to make them understand the role they would have to play in battle when serving as officers belonging to any special arm. The third term I taught them the elements of war administration, such as lines of communications, etc. I also gave four lectures on 
the elementary ideas of strategy, so that when the cadets read the history of a campaign they might understand it, although they might not ever have to apply the knowledge themselves. With regard to the careless reader, I think that some may misunderstand the suggestions offered by Colonel Hale for the cadets at Sandhurst. In these suggestions it seems to me from the diagrams before us that he has dealt almost entirely with the certain questions of strategy. So much depends on moral questions and the various powers and capabilities of different commanders, and even of the troops, that I think these diagrams per se are of little value. They assume that all the seven cadets and the ten cadets are of equal value, that the distances are equally easy to traverse, and that there is nothing intervening that would make it more difficult for one party to cross over them than another. In real war those parties represent units of a totally different value. The distances are no real guide, because there may be obstacles which may impede the movement of one party more than the other. Colonel Hale has himself told us that the cadet would leave Sandluurst "initiated into the art of war in the manner I have described. The cadet leaves Sandhurst thoroughly prepared for his work as a company officer, and with the theories of war secured in his memory.". Now it seems to me that those diagrams do not give him any idea at all of his duties as a company commander leading men in the field. I am sure Colonel Hale would repudiate that construction, but still the words are there, and a careless reader might take advantage of them and quote them against him. To me the power of the various arms of the Service is the principal thing for cadets to learn, and in the examples that are given them to illustrate these things they should be told that all strategy and tactics depend largely on human judgment. Even in reading books like Hamley's "Operations of War," one is apt to look upon strategy as a geometrical art. Really strategy and tactićs-however simple they may appear in the pretty diagrams to be found in various bookswhen you come into the field they are largely matlers of human judgment in certain circumstances and environnents. They are not matters of geometrical relationship such as could be expressed by diagrams on paper. As to modern mechanical inventions, they do nothing more than offer facilities for action by the use that is made of them by human judgment. The difference between great leaders and bad leaders is the good or bad use of their judgment in regard to these things. Colonel Hale tells us that the study of military history should be utilitarian. But I think it should also be suited to the rank that the officer holds. The cadet on leaving Sandhurst should certainly know the very elements of our profession, and the complaint I would make in regard to our military educational system is the gap that exists between the Sandhurst cadet and the officer at the Staff College. The Sandhurst cadet when he becomes an officer has not any real opportunities for the further study of the various branches of his profession until he goes to the Staff College. The various D.A.A. Generals for Instruction are chiefly employed in helping officers to pass promotion exams only. This serious gap between Sandhurst and the Staff College is, to my mind, one of the evils of our system. In conclusion, I should like to take exception to the definition of the word "study" which Colonel Hale has given us, namely, "The utilising by soldiers the recorded military experiences of the past." I should prefer to define it as, "The personal appropriation by soldiers of the recorded experience of the past, for the purpose of utilising it in the future." The mere study of experiences is not the same as their utilisation. What is wanted is the personal appropriation of those experiences in order to enable the soldier to opportuncly utilise them at some future period.

T. M. MAgtiRe, M.A., LL.D., Barrister-at-Law:-I certainly would not have dared to intrude myself upon the audience so soon after having occupied so long a time last week, were it not that Colonel Hale personally asked me to say a few words. I am sorry that these words will consist, in the main, of disagreement with Colonel Hale from beginning to end. But although that is so, I desire to begin by saying that I entirely appreciate, 
as other gentlemen do, the services of Colonel Hale; and I am willing to admit that $I \mathrm{am}$, in many respects, his disciple and follower. But I object, in the first place, to the change in the title of the lecture. If Colonel Hale had asked me to come down with a prepared speech on the subject, I should have found when I caine into the hall that the speech would not have suited the occasion. The title is, "The Professional Study of Military History," but it has beell changed into this, "The Utilisation of Military History for Immediate Tactical Purposes by Young Boys, and for Strategical Purposes by Generals"; but that is another thing altogether. I find that Colonel Hale, in the course of his lecture, confused three distinct things. What is generally known as strategy or military history? How do we distinguish strategy or military history? In colleges and books it is generally regarded as quite a distinct thing, not in its essence, but as a subject of study-quite a distinct class of study from tactics. I can quite understand that Colonel Hale might wish to alter that. He might teach that strategy and tactics are so closely connected, that we cannot tell where one ends and the other beginș. He discriminates between military history and strategy or tactics. The gallant Colonel pointed that out also. We have classes for strategy and military history; we have classes for tactics taught by different people; and we have classes for administration and law, with the details and organisation of Armies taught by other instructors; whereas Colonel Hale wishes to mix up in one lecture the whole three -strategy, tactics, and the composition of the corps. Therefore his lecture is not one about military history as it is generally understood, but a lecture about three things that are different according to common usage. That, I think, is to some extent a flaw in the lecture, and tends to confise people who may have intended to prepare speeches on the subject. Coming to the lecture itself, the gallant Colonel referred to the pictures on the board. I see these "in my mind's eye, Horatio," every day in my life, and on boards too. I think the gallant Colonel means by the first picture what Hamley would call interposing between parts of a divided front. He ridiculed the chessboard system of Hamley. I put it to the gallant Colonel if it would not be as well to take the campaign of Napoleon-one of the best campaigns in 1796 ; Napoleon being $A, B$ being Colli, and $\mathrm{C}$ being the Austrian Beaulieu-if a statement of that would not have been just as well as the letters $A, B$, and $C$, and if it would not interest people more. Also, in the case of convergent lines, the first German Army in Bohemia, in 1866, being at $B$, and the second German Army being at $C$, and Benedek being at $A$, would not that be just as good an Wustration as the alphabetical letters of the gallant Colonel? I think I recognised in drawing No. 2 on the board my old friend "forming front and flank." Now, suppose instead of $A$ and $B$ we put in Lord Wellington and Marshal Marnont; would not the ordinary Sandhurst boy like it just as much?. I know when I was a boy I would have liked it a great deal more. Then, taking No. 3-that is our very old friend-interposing between an enemy and his base. I think Colonel Hale will admit that it is so.

Colonel HaLE :-I will not commit myself.

Dr. M.tucine:-Colonel Hale is a wise man, and he will probably not commit himself to anything; but I give him a chance of attacking me. This is interposing, as far as I can sce, between the enemy and his base: very well-fed belligerents interposing between badly-arrainged belligerents. Would it not be better to put Napoleon coming in between the Austrian General Melas at Marengo, or Napoleon coming down to the Danube in 1805? It would not take a bit longer. It would only take the same length of time as the gallant Colonel took in referring to those three things. Mine would be a living illustration, though the people were dead, and it would be an interesting illustration; whereas his is a mere chessboard or mathematical illustration of military history, if I may use the phrase. Now we come to the campaign of 1815 , and the conduct of that examiner at Sandhurst who ventured to ask young English gentlemen what was going on in Belgium in a crisis for their race and name on the 17th June, 1815. Why should 
he not ask them that? There is not a tinker or tailor, or soldier or sailor, in Great Britain that ought not to know all about it, let alone the Sandhurst or Woolwich cadets. It is part of the heritage of the nation at large, and they are there to be educated to be proud of themselves, as well as to become tacticians, organisers, and administrators. Surely Colonel Hale will admit that the examiner merely wanted to illustrate these points. Why was Blücher at Waterloo? Why was Grouchy not at Waterloo? That is the meaning of asking what occurred on the 17 th of June. I will now come to Hamley. Undoubtedly with the present state of military education, and education at large anong our pcople of all classes, Hamley's w'as a hard book. Why was it a hard book? Because gentlemen coming from public schools and going to Sandhurst and Woolwich had not the rudiments of modern history in their minds. Every French and German gentleman of the same class, and every Russian and United States gentleman of the same class, is familiar with the ordinary course of European history. There are little manuals published abroad and used abroad-quite convenient books-and I am sure the gallant Colonel will admit that any fair knowledge preliminary to the study of Hamley and of modern European history would enable one to follow the campaign of Eckmühl with ease. I used to refer gentlemen to certain pages of Alison. If they read certain pages of Alison and then went to Hamley, Hamley became to them at least as interesting as "The Adventures of Dr. Nikola," or "The Sorrows of Satan." Now, the gallant Colonel says that this teaching of history from the past to the present, instead of from the present back to the past, is obsolete. He says, "Begin now and go backwards; any other plan is obsolete." Would the gallant Colonel mind telling me where it is obsolete?. It is certainly not obsolete in England, because he says it is going on, and he complains of it going on. Is it obsolete in France? It is in vogue in France, and it is the method adopted in Kraft's book on strategy, 1859 and 1870 ; it is the method adopted by Rustow and Vial. Turning from books to schools-to his beloved German-why does not the gallant Colonei-adopt his system? Colonel Hale says that he prefers the old system that Napoleon preferred; but Napoleon did not begin by studying the operations of Frederick the Great : he begain by being commended heartily by his instructors for understanding the campaign of the people mentioned in Plutarch's Lives as a cadet. He was a most diligent student of military history all round; and when he became an officer, he did as Colonel Lonsdale Hale says-he sent for the most recent illustration of operations, as in Italy in 1743, or by Prince Eugène before he went there in 1700, before going himself into action in 1796. What is the course in Germany is arranged for the German War Academy no longer ago than 1895? There are two classes (this, according to the Colonel, is obsolete). This is the newest recominendation of the German Army with regard to military history : -

"A thorough knotcledge of hislory forms an essential part of a general education, and is in many respects of the greatest use to crery officer in his profession. Four hours the week will therefore be allotted in the first and second class to history lectures, and these ought to form the foundation of this subject, which will be obligatory. In the first class the lectures treat of the period 1500 to 1789 , viz. : (1) A summary of the development of Europe as far as the Reformation ; (2) the history of the revival of learning and the Italian Renaissance; (3) The history of the Reformation in Germany with an outline of the constitution of the Empire and the social status of the different classes. The Reformation in England, France, Sweden, the Netherlands; (4) the Thirty Years' War, the English Revolution, a French history to about 1673 , the revival of history, and literature, and philosophy ; (5) the detailed history of the Great Elector, the development of Eascern Europe in connection with Prussian history as well as the change wrought in the political system of Western Europe through the Spanish Succession (i.e., Marlborough); (6) the time of Frederick the Great, an occasional explanation of his wars and 
battles, and a continuous description of the whole intellectual bent of the ISth century, literature, philosophy, and legislation ; (7) Catherine II., and the first and second partition of Poland. In Class II. history since 1789, viz. : (1) the development of England as a colonial Poner, the American War of Indcpendence, the contemporary state of France, an explicit description of the French Revolution; (2) Napoleon's career till 1812, Alexander of Russia ; (3) the material and intellectual state of Germany, especially of Prussia, the Stein.Hardenberg legislation, Schleiermacher, Fichte, Schelling, Hegel; (4) the War of Liberation, the Vienna Congress; (5) European policy, the literature of the Restoration; (6) the intellectual life of Germany in State and Church as far as 1848, the demands of the English people for reform; (7) the national bent of the people of Europe and the Revolution of 1848 ; (8) Napoleon III. and the War in the East (i.e., Crimean War); ( $\theta)$ German history from 1864-71, constitution of the German Empire, the economical, socialistic, and communistic movements. Close consideration is hereby to be given to Prussian history in this sense-how the BrandenburgPrussian State has, through the genius of its Princes and through the earnest work of its people, entered firmly with ever-increasing importance into the rank of great Powers. "This should be clearly taught."

These few suggestions I commend to the lecturer, not because I am not thankful to Colonel Hale, but because he asked me to criticise his lecture; and these are a few criticisms to which, before sitting down, I will direct his attention.

Lieut.-Colonel J. A. Fergusson (p.s.c., Professor of Tactics and Law, Royal Military College, Sandhurst):-Colonel Hale was a professor at the Staff College when I was a student, and I assure him that the attitude of my mind towards him is the same now as it was then, so that I desire to speak with the utmost deference to him. He has invited me to join in the discussion, and I therefore ask him to allow me to make a few criticisms on what he has said. In the first place, $I$ join issue with him as to the value of the old campaigns, and I will read one of Napoleon's Maxims in support of my opinion. He says:"Read and re-read the campaigns of Alexander, Hannibal, Casar, Gustavus, Turenne, Eugene, and Frederick; there is the only means of your becoming a.great captain, and acquiring the secrets of the art of war. Your genius enlightened by this study will make you reject the maxims opposed to those of these great men." Now I assure you we do not under-value the Franco-German war. At Sandhurst, in every lecture throughout the whole course of tactics, we borrow our illustrations from the war of $1870-71$. If we want to talk about woodfighting, we go to Wörth and discuss the attack on the Niederwald. If we want to speak of the attack and defence of villages, we go to Noisseville and Neuilly; and so on throughout the course of tactics. We cannot, therefore, be charged with neglecting the lessons of the Franco-German war. But when the study of military history was added to our course at Sandhurst, we had to think (with the very limited time at our disposal) what were the best campaigns to select. In the old days there was a Professor of Military History, with an assistant who did nothing else but teach that subject. I am responsible for the work of the tactical branch of the Royal Military College just now, and we have to teach in one-third of the time allotted to cadets not only the whole of minor tactics, but military law and military administration, including a thorough knowledge of the soldier's accounts. The one object that we set before us is to turn out the cadèt a good regimental officer; but, added to this work, there is also a musketry course, in which we give both practical' and theoretical musketry instruction. You see, therefore, the short time we have at our disposal for this great subject. I am not ashamed to say that yesterday I lectured on the battle of Waterloo. - In our choice we selected the greatest battle of Wellington, and the greatest battle of von Moltke. During their second term the cadets have four lecturer spon the campaign of Waterloo. During their last term the cadets have some lectures on 
the battle of Gravelotte, with an outline of the incidents leading up to it, in order to make it intelligible. Also, when time permits, they have lectures on the Crimea, but not for examination purposes. It is not $\mathrm{my}$ business to criticise the decision of the authorities. We do.as we are told. We are told to teach military: history, and we do the best we can in the time. Some of us might, perhaps, prefer to have popular lectures given on military history at the Royal Military College without an examination upon then. We have, however, 'no reason to complain of the want of interest taken by the cadets. Althougl we do not boast the charm of the present lecturer, and have not got his rhetorical skill, still cadets do listen with the deepest interest to the lectures they hear. And it is not only to teach tactics and strategy that the little military history we teach is of value. What we aim at is to secure that the cadets should be interested in the study of military history, and should follow it up when they.join the Service. But I am prepared to defend the study of the campaign of Waterloo and the battle of Gravelotte. After all, we do not go much into strategy: The first example, however, which has been put on the board by our lecturer, is illustrated in the campaign of Waterloo. If you put $\mathrm{N}$ for $\mathrm{A}, \mathrm{W}$ for $\mathrm{B}$, and $\mathrm{B}$ for $\mathrm{C}$, it is pretty much what happened in that campaign. I quite agree with Dr. Maguire that it would be nuch more interesting to study examples from actual history than the very bald examples on the board. Surely, from the battle of Waterioo many tactical lessons may be learnt. If I had to select a battle illustrating the desiderata of a defensiye position, I do not know that I could go to a better instance than Waterloo. There is first of all a gentle slope to the front and a clear view and field for fire; perfect communications throughout; the slope to the rear covering the cavalry and covering the reserves; the line of communication perpendicular to the front, and so on. Dozens of illustrations of tactics, I think, may be obtained from the battle of Waterloo.' But I plead for a study of Wellington's campaigns on other grounds. I think it would be a sad pity that it should go forth from here to the world that an English lad ought not to study Napier's "Peninsular War." Surely, the study of the brave deeds of our countrymen of old stimulates emulation, fires the young officer, and instils into him something of an ambition to follow the example which has been set him in bygone days.

Captain W. H. JAMEs (p.s.c., late R.E.) :-I think that Colonel Hale's lecture has been an exceedingly valuable one; but he will forgive me for saying that $I$ think if he had let himself go he would have made it still more valuable. I suppose that the caution which is born of the study of military operations has prevented him from giving vent to his feelings in his lecture this afternoon. I perfectly agree with him on one point, which is, that we should begin our studies rather from the later campaigns than from the earlier ones. If I am to take an individual, and show him the course which would be best to train him as a General, I should say he ought to read everything; but, unfortunately, time does not allow that; and if you seek to instruct men, whether they be cadets or whether they be officers, in the art of war, you must necessarily limit your course for the purposes of illustration. Now, there is one great reason why it is better to go to the newer campaigns rather than to the old, and that is the reason which $I$ think Colonel Hale extremely well expressed in the phrase which he used in his lecture-" the mechanical conditions of war." The mechanical conditions of war change very much. To study the old wars for strategical purposes, and to deduce from them strategy for modern use, would, in my opinion, be extremely fallacious. It would be very easy to multiply examples. Take the campaign of 1796 in Germany; one great reason why the Archduke was successful in that was that he turned away from the front of Moreau and went against Jourdan. Moreau was himself ignorant for several days of what had occurred. It is difficult to believe that if modern conditions had obtained, if the ubiquitous

1 Wherz could you find a better example of what a cavalry charge ought to be-sudden, swift, and timely-than that of Somerset's and Ponsonby's brigades? -J. A. F. 
newspaper had been in existence, if the still more ubiquitous newspaper correspondent had been attached to either Army, something would not have leaked out which would have given Moreau an inkling of what was going to occur. Again, take the campaign of Marengo. A campaign like that would be an absolute impossibility under modern conditions. Under no circumstances is it possible to conceive that Napoleon could have got together the so-called "Arny of the Reserve," and that he could have led that Army across the Alps and come down like an avalanche on the unprepared Austrian commander, who was in absolute ignorance of his great adversary's movements. Such action would be absolutely impossible nowadays. The news would have got round, perhaps through a circuitous route; but it would have reached Alessandria, and Melas would have known who was against him, and whence he was coming. This being the case, it is far better to go backwards. I do not in the least degree object to the study of these old campaigns; all kwowledge is useful, and the study of the canıaigus of Napoleon will always remain masterpieces for those to study who have the time to do so. But if the time is limited, they had better take up more modern wars; because until they understand modern methods, they are not in a position to deduce proper lessons from former campaigns. There is another reason why it is well to go to modern campaigns rather than to more ancient times, and that is, that we know so much more about them. A man whom I look upon, and who is looked upon in Germany-though I believe one or two obtuse Englishmen do not agree with me-as one of the greatest German military writers, the late Prince Hohenlohe-Ingelfingen, gives an amusing description how, when he was at the KriegsAkademie at Berlin, he was in the habit of criticising the movements of great generals, of saying that Napoleon was stupid in one direction and Frederick in another; but he justly remarked that that is an easy sort of criticism, and that unless you can put yourself in the actual position in which a great commander was, unless you know all the facts which determined his conduct, you had better leave the criticism alone. That is the reason why modern wars are much better studied than ancient ones. Of course. I know that if you go to the pages of the German official account, you will not find these things recorded. For example, with regard to the orders of Prince Frederick Charles before the last day of fighting round Le Mans. The first set of orders were prepared, but never issued, as in the meantime, information came in that the Xth Corps had entered the town. $\mathrm{He}$ had prepared for a situation of doubt, a situation of what might have been disaster. He had prepared those orders on what he knew; but information came in which totally changed his views of the situation, and fresh orders were issued. There is no record of that kind in any of the old campaigns. You do not get what the French call the rie intime of military life in the old records. Then contrast the campaign of 1806, as given by Sir Edward Hamley, and as given in the fuller treatises of Foucart and Lettow-Vorbeck. There you have tle words of tiwo modern first-rate military writers, putting before you the thousand and one different factors which went to determine the situation from day to day. I do not know of any ancient war with regard to which you have such information available if you wish to read about it. That, as I have said, is one great reason why, to my thinking, in military study we should begin with that about which we know most, and about which we can gret the greatest information. One good example of the value of the study of military history in all its intimate details, is the contrast between the conduct of the Prussian organisers and leaders in the war of 1866 and in the war of 1870 . 1S66 was the "prentice hand" of these great men, when they learned war by experience, and afterwards knew what alterations were required. They changed their views in the use of artillery, in the use of cavalry, and the way in which they formed advance guards, and so on. Again, they improved their system of supply. That was the result of what they did in 1866 , and immediately after 1870 you see the same process going on. They again set to work, not resting idly on their laurels, to see what lessons were taught by 
the war, so as to improve and bring up the Army to the highest possible pitch of perfection. We sometimes hear the foolish remark that these things are "made in Germany:" Fortunately for us they are so.. They are made in Germany because we have not had war brought home to us in the way that the Germans have had it brought home to them; and, for my part, I only hope that all the lessons of war will be made in Germany, or Belgiun, or France, or anywhere else except in our own country. There is ne thing I am fully convinced of, that is, the value of the study of European war. It is by no means sure that at the end of this century we may not be engaged in a European war; and as long as there is that possibility before us we should bage the education of our soldiers on European warfare. There is another good reason why this should be done: savage warfare, say in India or in Africa, is merely European warfare with a difference. The strategy does not differ. The strategy which we should employ if we were leading an Army of a million men against the French would be precisely the same as we should employ in leading 5,000 men against the $Z$ ulus. We should, in either case, endeavour to annililate the enemy's field force, and at the same time to cut off his source of supply. These are the two main points of strategy, applying equally to savage and civilised warfare. Moreover, with regard to tactics, you cannot base tactics, at any rate the manourring portion of it, on conduct against savages armed with inferior weapons. But if as the foundation of your tactics you have laid down, by study and consideration, those principles which are right against a civilised enemy, then, mutatis mutandis, you can use them against inferior satrages. It is for these reasons that I deprecate the statement that it does no good to English officers to study Europcan war. If you do not base your studies on European war, you will never be able to meet the savage. Similarly, I hold that for the general study of war, while it is undoubtedly useful and desirable to study wars fought out by the great masters of the art on the various theatres of war-as Moltke did, for instance, previous to 1866, but as the Austrians did not do-however desirable it is to follow out the movements of the ancient masters, still it is essential that our teaching of the military art should be based on those conditions which prevail at the present moment; and the differences between these and those obtaining in former wars must be borne in mind if the study of the latter is to be of any utility.

Mr. H. SPENSER Wilkissox:-As an outsider I feel a certain amount of surprise, at the course which the discussion has taken.' Attracted by the title of Colonel Hale's paper, I came here in the hope of hearing something about the professional study of war; and I am much disappointed to find Colonel Hale, and most of the officers who follow him, discussing the study of military history, as a matter for the instruction of boys, or for officers of the Army who have no time. I understand by the professional study of a subject, its study by those who are competent to deal with, and the principal part of whose lives is devoted to the subject in question. I am perfectly startled to hear the theory put forward that the British officer has only time to become acquainted with one campaign, or perhaps one and a half. In any other profession-in the profession of the law in which I was brought up, or in the profession of medicine-it is generally expected that the competent man not only understands the practice of his own day, but has learnt the development of his science from the beginning; and I should have supposed that by the professional study of war we meant that kind of knowledge. By history, I understand the course of development; and I should have expected the professional study of military history to mean the development of the practice, and the history of the principles governing it, from the beginning of time to the present day. But I find no conception of that hind in most of what we have heard. Of course, any study is undertaken with some object. What are the objects that we have heard of? Colonel Hale puts the whole matter as though it were the way in which a young officer was going to learn how to command a company. I put it to you as professional soldiers, Will a young officer be made

vol. XII. 
much better able to handle his company, because he has studied past campaigns? I think you will probably say, that all that he will gain in the management of his company from studying past campaigns is a certain amount of illustration of what may be done with a company from those not very numerous cases in which the very detailed actions of companies are recorded. How few are the past actions in which we know in full detail the precise object of the captain handling his company in battle! Colonel Hale used a phrase in the course of his lecture to the effect that tactics consisted in the application of the weapons of the epoch at which the battles take place. Where can you find a campaign fought with weapons resembling those of to-day? Colonel Hale informed his audience that the battle of Waterloo was fought in 1815 , his point I suppose being that it was a long time ago. One might remind him that the Franco-German war was fought in 187027 years ago, and that instead of the very inperfect breech-loader with which the Germans were then armed, all Armies are now armed with the magazine rifle, and in a short time the old field gun will probably be changed for the quick-firing field gun. I very much doubt whether you will get much more practical hints as to the managenient of a company, apart from the question of morale, from the war of 1870 , than from the campaign of 1815 . The advice of Napoleon to officers to study military history has already been quoted. He advised them to read and read again the campaigns of the great masters, beginning with Alexander the Great. Does anyone suppose that when Napoleon said that, he was giving advice to a company officer as to how to lead a patrol? I take it that he thought that military history was a study from which those who were likely to be responsible for the management of a war would learn how to conduct it, and that it was for governments and commanders that this study was necessary. When I hear it said that this is impossible, and that these campaigns are too many, it occurs to me that much more in our own time than in Napoleon's the man who is in the least degree likely to be called upon to command an Army in the field, or advise a Government on the conduct of a campaign, will not be a young man of twenty-five or thirty. It is very unlikely that he will be as young as Napoleon in his first campaign-the experience is that he is usually already a grey-headed gentleman; and I think that in the course of his life up to that time if he is a professional man, he ought to have had time to master the secrets of his profession, including military history. As to the method of study, my friend Colonel Hale has not, I think, very fairly criticised General Hamley's text-book. As I was, I believe, the first writer on military literature who criticised rather severely General Hamley's book, I nay be allowed to say a word in its defence. If the book is to be taken as the last word on military history, no doubt it is not satisfactory, because you will not get from it the whole conditions in which a campaign is fought; but I take it that that was not General Hamley's object. I take it that what he wanted was to write an elementary treatise on the principles, of strategy, and for that purpose he found it desirable not merely to give definitions, but to illustrate them; and if we read his book as a series of definitions with illustrations, I certainly say, in spite of all that has been said against the book in past times, that $I$ do not think any better book of the sort exists in any language. But if you read General Hamley's book and stop there you will get a very distorted idea of the different campaigns, because his purpose is merely to illustrate from different campaigns what is meant by such expressions as "interior lines" and those things which Colonel Hale has put on the board. Although Colonel Hale condemns General Hamley, he appears to me to stand on Genera! Hamley's ground, because when he talks about strategy he says, speaking of his favourite campaign of 1870 , that the student will find there the examples of strategy that he wants. What is the strategy that Colonel Hale wants? It consists in such ideas as forming front and flank and an Army placing itself across its adversary's communications; in other words, he is anxious to illustrate certain elementary definitions. I happened yesterday to be making a reference to 
Marmont's little book called "The Spirit of Military Institutions." In reading the preface I was much struck by what, was said by Marmont, perhaps the most serious student among the brilliant marshals of Napoleon. Marmont says that the study of military history is very valuable, because it gives certain eternal principles of which the application is very difficult. Then, again, he says that one of the greatest masters in his business who ever lived was Napoleon. What does he say of Napoleon? How does he show that he was a great strategist? He does not say that he knew all about interior lines, forming front to a flank, and so on; but he says that nobody knew better where to strike his blow: nul n'a miezex su reconnaître d'avance le point oil il devait frapper. I think a great deal of advantage would be gained in a professional study of military history if we were much more accustomed to ask ourselves the large question on which the opening of all campaigns depends-why did the general, in the first instance, choose the particular course of action which he followed? Colonel Henderson has well reminded us that war is a political matter; that it is a quarrel between two Governments, and that before you can have a war wellconducted, the Government must know its mind, must know what it wants from the other Government, and by what process of force it can compel the other Govern. ment to change its mind; and in making up its mind as to how it will apply that force, it requires strategical advice and knowledge ; then you require the general to execute the plan which he has suggested, and put before his Government. I am now speaking, not as a professional soldier, because I am not one, but as a student much interested in watching the progress of professienal thought in the British Army. I see here professional men discussing professional study, and taking it on the level of what is to be done with school-boys. I will venture on a second instance of where I think the professional study of the British Army falls short of what it should be. I am speaking, not to cadets, but to distinguished officers like yourself, Sir, whom we look upon as the great leaders of our Army. We have heard Colonel Hale telling us about the Franco-German war. He tells us these battles were more modern than the battles of Napoleon; and Colonel Henderson tells us how certain strategical combinations are better illustrated by it than by the battles of Napoleon. During the last three years you have had published the whole of the strategical discussions and investigations worked out by Moltke before he began his campaigns of 1866 and 1870 , whereas, until a few years ago, you did not know what Moltke was driving at except by inference from the opening moves of those campaigns. You can now follow every modification of those plans to suit the political situation existing at the time. But, although those books have been published for two or three years, I have looked in vain to this Institution, and to our professors of military history, to see some comparison of those movements with similar discussions and considerations which have guided previous campaigns. I agree with our lecturer in saying that military history should be studied backwards in this sense, that no one can venture to examine or criticise the operations of a general, unless he is himself a competent man. If a man cannot himself sit down and say "In this position those are the orders I should give, those are the arrangements I should make for this division and that division," if he has not accustomed himself to work out a campaign as a series of problems which he endeavours to solve, I should say that his criticisms on the operations of a general in the field will be worthless. It is the professional man, the man whose business it is, or might be, to conduct operations, the man who will take pains to put himself in the commanders place, and then criticiseit is such a man who will throw light upon the subject. Before he can do that he nust have learnt his business as a soldier by professional study. I can understand attempts made by a man who does know his own business as a soldier, and has made himself a competent general, to examine the course adopted by a number of previous generals, and, by a comparison of the exper:nnce of Frederict: the Great, Moltke, and so on, to discover what are those general principles of 
which we hear so much, the application of which differs from time to time; and I believe that, by starting from the political situation and asking one's-self what was the object which the two Governments had at the beginning of the war, and how the general could endeavour to attain that object, and how he proposed to make his movements tell on the decisions of the opposing Government-starting from that we may get a clue to what happened in a good many campaigns, and, by a comparison in that way of a sufficient number of campaigns, we shall see something of the development and the nature of war, and so see that war in every age is the reflection of the general state of society and civilisation of the time in which it is carried on.

The Criarruxi: (Major-General Sir WV. F. Butler, K.C.B.) :-The extremely interesting paper which we have heard, and the exhaustive discussion which followed it, have left the Chairman very little to say-very little, at any rate, that can be regarded as original-because the ground has been perfectly covered. I think we are all agreed with Colonel Hale-there was no difference of opinion on that point even amongst those who differed so much from him-as to the desirability and necessity of the study of military history. The difference arose in regard to the method of application of that study-whether it was to be read backwards or forwards. As a free-lance in the study of military history, it seems to me that so much was shown on both sides, that the truth probably lay somewhere between the lecturer and his critics, as is often the case in these matters of difference. The only question, it appeared to me, that was not covered either in the lecture or the discussion was that military history must be, from its very nature, an imperfect record of the truth. That is a very wide statement, but $I$ think $I$ can prove it. So far as the lesson conveyed by military history is concerned, its most valuable part must be a lesson of defeat, just as doctors study disease in order to arrive at health. Now, I do not think that the beacons or marks, or whatever they may be called, which are set up in military history for the guidance of students are always accurately and justly placed, and the worst of it is that the nearer we approach the time under review-the nearer it is to us-the less likely are we to find these buoys or beacons placed upon the particular shoals and rocks which they should indicate. Few men who write history, especially military history, do it for the mere sake of abstract truth. They approach the subject from other points : they have to think of their patrons and theic readers, and, more than all, they think of their own prejudices and partialitics. But far be it from me to disapprove of, or throw cold water upon, the study. On the contrary, I believe that the very widest and most extensive study of military history is not only desirable, but absolutely necessary to the developinent of the military mind. All I contend is, that we do not possess, and I do not think any nation possesses, a really accurate, sound, truthful text-book upon any of the military events of the last forty years. The great advantages of the old books is that we may be sure they are pretty fair. When we speak of Hannibal and Cæsar, we have no prejudice in the matter. But it is a very different thing if you begin at the "prehistoric time of 1815 ," for then our prejudices were hot, and our partialities still glowing. That, I think, is the reason why it is necessary to go back to earlier examples, because we are sure that we are dealing with a fair and just cstimate of the age. Take, for instance, the campaign of 1815 , or the expedition in the Crimea; have we any just, true, and accurate account or explanation of all the causes underlying the disasters in these campaigns-in which as much is said, and as fairly said, on one side as on the other, like the summing-up of a judge before a jury? If we have, I certainly have not read it. I doubt if such a work exists, even in regard to the campaign to which Colonel Hale las directed so much attention; in fact, the nearer we come to our own time, the more rampant-will be the prejudices, and the stronger the partialities. The great strategic principles of war, to my mind, vary only in their application-their essence remains the same; 
but they are not for every-day use-they must remain the study of a few mindswhat can be for every-day use is that part of military history which deals with, and teaches, the tactical or intelligent application of means to ends. The use of brain in directing the effort and labour of the body, and above all that higher mental culture so difficult of definition, was undoubtedly in the mind of Charles Gordon when he wrote from Khartoum as one of his last messages, that the study of Plutarch's Lives was of greater consequence to a young officer than all the major or minor tactics ever written. Gentlemen, I am sure that I voice your united feelings when I convey to Colonel Hale our sincere thanks and appreciation for the paper he has read to us. Colonel Hale has been identified perhaps more than anyone now living with the study of the teaching of military history. He informed me when we were coming to the hall, that it is now twenty-one years since he gave his first lecture in the neighbouring hall of this Institution. That is a long period. No critic has a bed of roses, and least of all a military critic; and we owe all the greater thanks to Colonel Lonsdale Hale that, through storm and sunshine, he has always openly and fearlessly spoken bis mind on all military questions. That is not always an easy thing to do. No matter whether we differ from him or agree with him, we must all recognise that no more ardent teacher has been among us; and even though some of us may disagree with many points in his lecture, we owe it to him that he started the hare which has given us so much interest this evening.

\section{Note by the Lecturer:-}

The best method of studying military history has lately been a subject of keen discussion. One of the chief objects in the delivery of my lecture was to obtain the views held on this matter by officers qualified by experience and knowledge to pronounce opinions upon it. Each officer who took part in the discussion had, therefore, received from me beforehand a printed copy of the lecture. The speeches may consequently be fairly regarded not merely as replies to the lecturer, but as carefully-considered expositions of the views of the speakers on the study of nilitary history, and as such they are of special value. Readers of the JourNal have now before them a number of separate short essays on the matter, and will be able to form their own opinions thereon. Naturally, I hold to my own views, for "a man convinced against his will is of that opinion still." Moreover, I think that sometimes the speakers had a little misunderstood me. I desire to record my obligations to them for having taken the trouble to come and take part in the discussion.-L. A. H. 